\title{
기술보고
}

\section{Development and Research Trends of TBM Manufacturing Technology in China}

\author{
Nan Zhang ${ }^{1)}$, Hoyoung Jeong ${ }^{1)}$, and Seokwon Jeon ${ }^{1) *}$ \\ (Received 12 June 2018; Final version Received 27 August 2018; Accepted 29 August 2018)
}

\begin{abstract}
Chinese TBM industry has rapidly developed over the past decade, while China can be regarded as the most remarkable TBM market in the world. After sixty years of development, China already has a complete set of technologies in all domains of TBM, including design, manufacturing, operation and tunnel construction, which are still evolving. The growth of the technology is a result of continuous research and development by the industry and academia under the strongly support from Chinese government. In order to complete independent technology development and play a leading role in the global TBM market, the strategy of China has a good reference value for Korea. The history of TBM technology in China was reviewed, and the major research projects and achievements were summarized. Finally, through the implications from the Chinese case, the research and development of TBM technology in Korea and its future research topics were discussed.
\end{abstract}

Key words : Chinese TBM technology, TBM manufacturer, Shield TBM

\section{Introduction}

Along with the booming of China's economy, the rapid urbanization in China has propped up the demand for the development of urban transport systems (Hong, 2015; Hong, 2017; Wang, 2017). Since the first subway was built in Beijing in the 1960s, a total of 32 cities in China opened rail transit operations with a mileage of $4,750 \mathrm{~km}$ by the end of 2017 (including maglev and tram). At present, 53 cities have set subway construction plans with a planned mileage of $9,000 \mathrm{~km}$. It is expected that $6,000 \mathrm{~km}$ of operating mileage will be achieved by 2020 . In addition, to ensure the sustainable development of urban cities, the Chinese Government has actively promoted the construction of utility tunnels. A total of 69 cities in China are building utility tunnels with the total length of $1,000 \mathrm{~km}$, and the construction cost is estimated to be 88 billion (RMB) (Yang and Peng, 2016).

TBM is usually categorized into shield TBM and open (or gripper) TBM. Shield TBMs have been mainly used for soft soils and composite formations, where the applications

1) 서울대학교 에너지시스템공학부

*Corresponding Author(전석원)

E-mail; sjeon@snu.ac.kr

Address; Dept. of Energy Systems Engineering, Seoul National University, Seoul, Korea are mostly subways and cross-river tunnels. Open (or gripper) TBMs are mainly used for mountain tunnels and diversion tunnels in hard rock formations. This paper will mainly focus on the development of shield TBM manufacturing technology in China.

In the context of huge domestic transportation construction markets, the demand for TBM manufacturing is high and thus, the Chinese TBM industry is growing at a high rate. According to the statistics from the China Construction Machinery Association (CCMA), the total sales of TBM (in number of units) in 2016 increased by $46 \%$ year-by-year (Fig. 1). In 2017, China has become the largest manufacturer and the largest market of shield TBM in the world (CCMA, 2018). The Chinese shield TBM market will grow to a scale of approximately 7 billion (RMB) by 2020 (Hong et al., 2013).

Recently, Chinese TBMs have become popularized and have rapidly occupied the domestic market while gradually entering the global market. The TBM industry of China has successfully transformed from "assembled in China" into "made in China" (Chen et al., 2016). The remarkable progress of Chinese TBM technology is based on independent innovation. A number of competitive Chinese TBM manufacturers have emerged including the six-largest TBM manufacturers: China Railway Engineering Equipment Group (CREG), China Railway Construction Heavy Industry 
(CRCHI), Shanghai Tunnel Engineering Co. (STEC), Liaoning Censcience Industry (LNSS), Northern Heavy Industries Group (NHI), and China Communications Construction Company TianHe Mechanical Equipment Manufacturing Co. (CCCCTH). They have captured more than $80 \%$ of the Chinese market share. The sales of major TBM manufacturers in 2016 is shown in Fig. 2.

\section{History of TBM technology of China}

The development of TBM manufacturing technology of China has gone through three stages (Chen and Zhou, 2017), namely, "early stage (1953-2002)", "technology innovation stage (2003-2008)" and "rapid development stage (2009 to date)".
In the "early stage (1953-2002)", the development of TBM technology mainly focused on several subway construction projects in big cities including Beijing, Shanghai and Guangzhou. STEC played an important leading role in the development of Chinese TBM technology in this period. The hand shield TBM, blade shield TBM, Earth Pressure Balance (EPB) shield TBM were developed in this period.

In the "technical innovation stage (2003-2008)", with the support from the "863 Program (National High-tech R\&D Program)", some key research projects were funded by the Ministry of Science and Technology of China (Table 1). Furthermore, through the introduction of advanced technology from abroad, China has developed TBMs with fully independent intellectual property rights narrowing

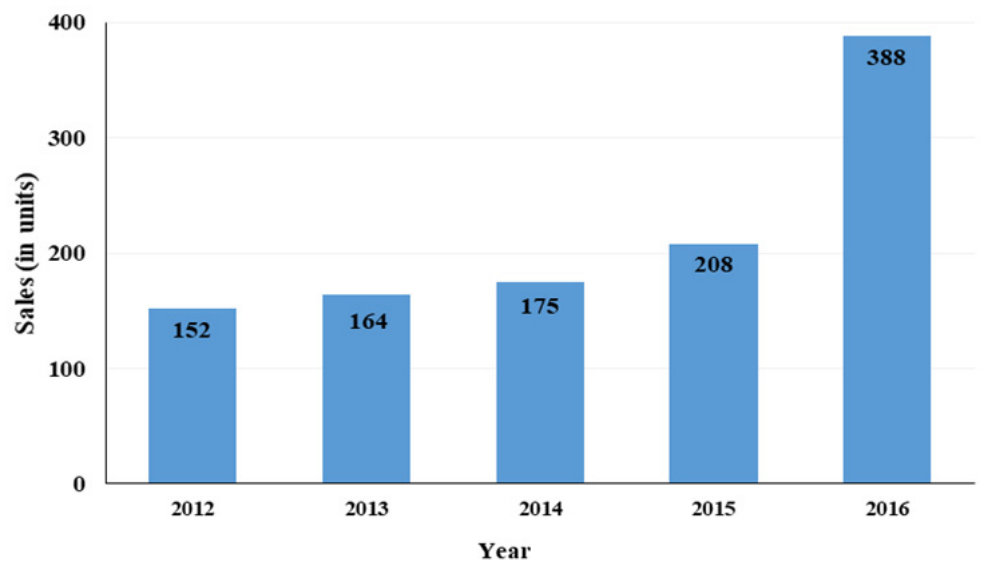

Fig. 1. Total sales of TBM (in units) in China for the period between 2012 and 2016 (from CCMA homepage).

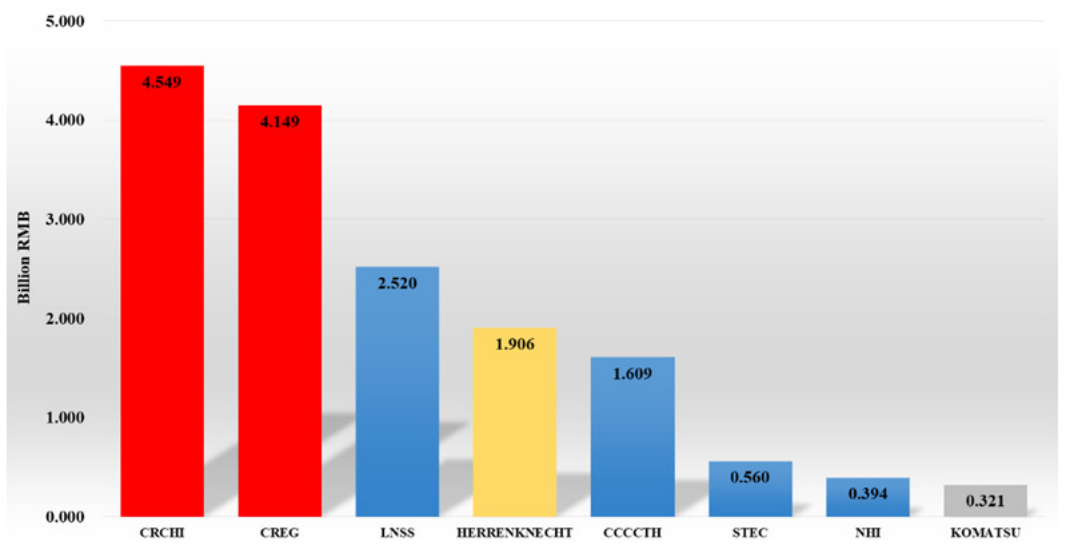

Fig. 2. Total sales of TBM (in billion RMB) by major TBM manufacturers in China in 2016. 
Table 1. TBM related research topics supported by the "863 Program”' (from Ministry of Science and Technology of China homepage)

\begin{tabular}{|c|c|c|}
\hline Research title & Leading research unit & Research period \\
\hline Design and manufacture of full-face TBM & STEC & $2002-2005$ \\
\hline Key technology of cutterhead and hydraulic drive system of shield TBM & China railway tunnel group & 2003.01-2004.12 \\
\hline $\begin{array}{l}\text { Key technology of cutting and measurement-control system of shield TBM } \\
\text { in mixed ground }\end{array}$ & China railway tunnel group & 2005.07-2006.09 \\
\hline Design of large diameter slurry shield TBM & China railway tunnel group & 2005.07-2006.12 \\
\hline Design and manufacture of main bearing of EPB shield TBM & LYC bearing & 2007.08-2010.08 \\
\hline Design and manufacture of high power reducer of EPB shield TBM & CITIC heavy industry & 2007.10-2010.08 \\
\hline Design and manufacture of heavy-duty hydraulic pump in EPB shield TBM & LiYuan hydraulic & 2007.10-2010.08 \\
\hline Comprehensive experimental platform of shield TBM & NHI & 2007.10-2010.08 \\
\hline Development of the prototype of mixed shield TBM & China railway tunnel group & 2007.10-2009.09 \\
\hline Development of the prototype of large diameter slurry shield TBM & STEC & 2007.10-2010.08 \\
\hline Research and application of key technology of large diameter hard rock TBM & $\mathrm{CRCHI}$ & $2012-2017$ \\
\hline Study and development on full-face tunnel boring general technology & Zhejiang University & $2012-2017$ \\
\hline Research title & Leading research unit & Research period \\
\hline $\begin{array}{l}\text { Basic scientific challenges in the design and manufacturing of large full-face } \\
\text { TBM }\end{array}$ & Zhejiang University & 2007.7-2011.8 \\
\hline $\begin{array}{l}\text { Basic research on the digital design of cutterhead and cutters based on high } \\
\text { performance rock cutting }\end{array}$ & CREG & $2010-2012$ \\
\hline $\begin{array}{l}\text { Basic research on intelligent control and support software for the whole process } \\
\text { of TBM safe and efficient tunnelling }\end{array}$ & CREG & $2010-2016$ \\
\hline $\begin{array}{l}\text { Study on the measurement and control method of electro-hydraulic system } \\
\text { and system integration }\end{array}$ & CREG & $2012-2013$ \\
\hline Key fundamental issues of Hard Rock Tunneling Equipment & Zhejiang University & $2013-2017$ \\
\hline Interaction mechanism and safety control between TBM and the deep mixed ground & Wuhan University & 2014-2018 \\
\hline $\begin{array}{l}\text { Basic research on the safety of shield tunneling in the Yangtze river with } \\
\text { high water pressure }\end{array}$ & ijing Jiaotong Univers & $2015-2019$ \\
\hline
\end{tabular}

the gap between Chinese and international levels Chinese TBM manufacturers developed their own technologies for the design of different types of TBM.

Based on the huge domestic shield TBM market, TBM technology of China entered the "rapid development stage" since 2009. Many research projects on TBM manufacturing and tunneling technologies were supported by the "973 Program (National Basic Research Program)" as listed in Table 2.

For decades of effort and development, major breakthroughs and achievements were successfully made in the development of key core technologies in shield TBM manufacturing and mechanized tunneling. Some notable shield TBMs made by Chinese manufacturers are listed in Table 3 and shown in Fig. 3.

\section{Research trend of TBM technology in China}

In recent years, research on TBM technology has become very popular in China. The number of publications related to TBM technology during the past two decades is 
Table 3. List of some notable shield TBMs made by Chinese manufacturers

\begin{tabular}{|c|c|c|c|c|}
\hline Manufacturer & Year & Type & Project & Remark \\
\hline CREG & 2015 & EPB & Tianjin Metro Line \#11 & $\begin{array}{l}\text { Largest rectangular shield TBM with } \\
\text { cross-section }(10.42 \mathrm{~m} \times 7.55 \mathrm{~m})\end{array}$ \\
\hline CREG & 2016 & EPB & Baicheng Tunnel, MHT J-3 Section & $\begin{array}{c}\text { First horseshoe-shaped shield TBM in } \\
\text { the world }\end{array}$ \\
\hline CREG & 2017 & Slurry & Shantou Bay Tunnel Project. & $\begin{array}{l}\text { Largest slurry shield TBM in China } \\
\qquad(\varphi 15.03 \mathrm{~m})\end{array}$ \\
\hline CRCHI & 2013 & Dual mode & $\begin{array}{c}\text { Shenhua Xinjie Coalmine Inclined Shaft } \\
\text { Project }\end{array}$ & $\begin{array}{l}\text { For long distance and high slope angle } \\
\text { of inclined shafts in coal mine, first in } \\
\text { the world }\end{array}$ \\
\hline CRCHI & 2016 & Slurry & Yuji Intercity Railway Project & $\begin{array}{l}\text { First large diameter slurry shield TBM } \\
\text { in China }(\varphi 12.77 \mathrm{~m})\end{array}$ \\
\hline CRCHI & 2016 & EPB & $\begin{array}{c}\text { Taiyuan Railway Hub Southwest Loop } \\
\text { Project }\end{array}$ & $\begin{array}{l}\text { Largest EPB shield TBM in China } \\
(\varphi 12.14 \mathrm{~m})\end{array}$ \\
\hline $\mathrm{CCCCTH}$ & 2010 & EPB & Shanghai Metro Line \#12, Section 26 & $\begin{array}{l}\text { For Deep buried high water pressure } \\
\text { tunnel under Yangtze River }\end{array}$ \\
\hline STEC & 2015 & EPB & Ningbo Metro Line \#3 & $\begin{array}{l}\text { Largest quasi-rectangular shield TBM in } \\
\text { the world }\end{array}$ \\
\hline NHI & 2011 & Slurry & Esfahan Cable Tunnel in Iran & First micro slurry shield TBM $(\varphi 3.14 \mathrm{~m})$ \\
\hline LNSS & 2015 & EPB & Chengdu Metro Line \#4, Section \#6 & $\begin{array}{c}\text { Highest tunneling efficiency of } 555 \\
\mathrm{~m} / \mathrm{month} \text { in cobble-boulder ground in } \\
\text { Chengdu }\end{array}$ \\
\hline
\end{tabular}

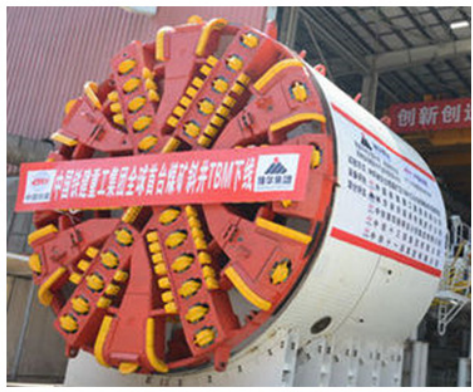

Dual-mode shield TBM by CRCHI ( $\varphi 7.62 \mathrm{~m}$ ) (Chen and Zhou, 2017)

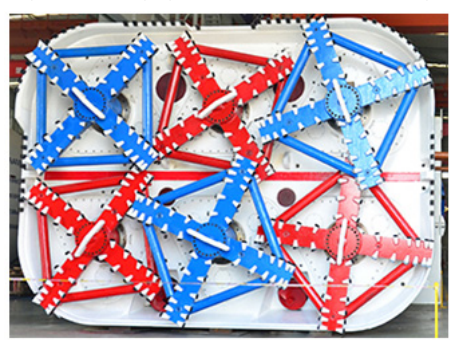

Rectangular pipe-jacking machine by CREG $(10.12 \mathrm{~m} \times 7.27 \mathrm{~m})(\mathrm{Li}, 2017)$

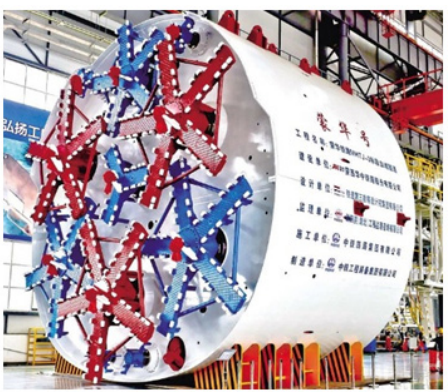

Horseshoe-shaped shield TBM by CREG $(11.9 \mathrm{~m} \times 10.95 \mathrm{~m})(\mathrm{Li}, 2017)$

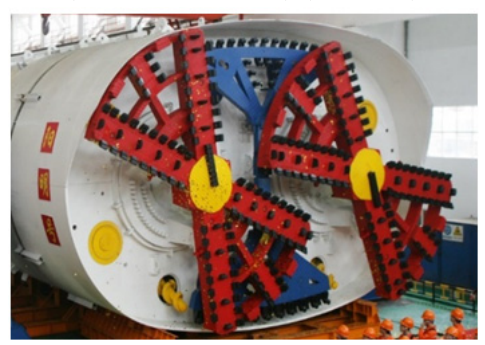

Quasi-rectangular shield TBM by STEC $(11.83 \mathrm{~m} \times 7.27 \mathrm{~m})($ Chen and Zhou, 2017)

Fig. 3. Some notable shield TBMs made by Chinese manufacturers. 
presented in Fig. 4(a). Based on the statistics from the China National Knowledge Infrastructure (CNKI), it can be found that Tongii University, China Railway Tunnel Group, and Southwest Jiaotong University are the most active research institutes in China (Fig. 4(b)). TBM related journals are listed in Fig. 4(c) and "Tunnel Construction" which is the most widely renowned journal in China. The research subjects in TBM technology are shown in Fig. 4(d), where settlement, cutter, grouting techniques are research hotspots. Although these publications are mostly

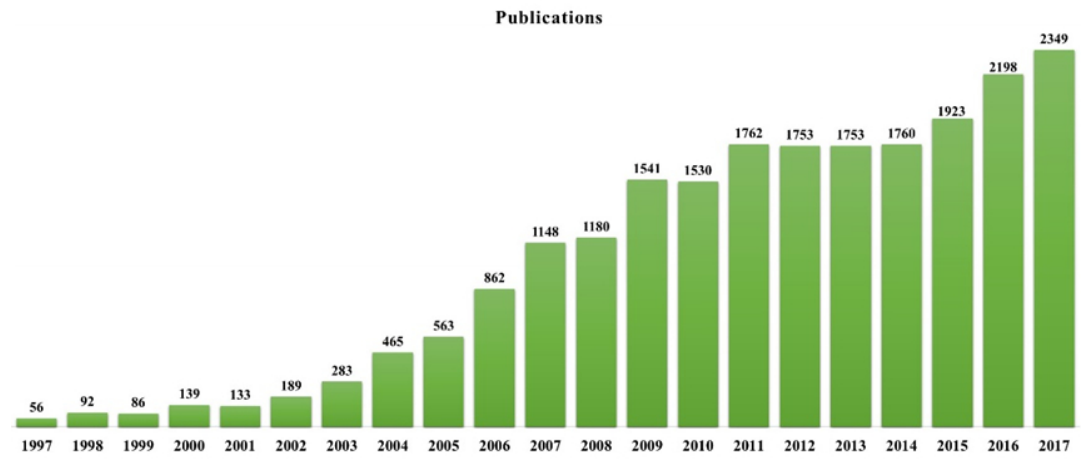

(a) Publications related to TBM technology

Research Institute (Top 10)

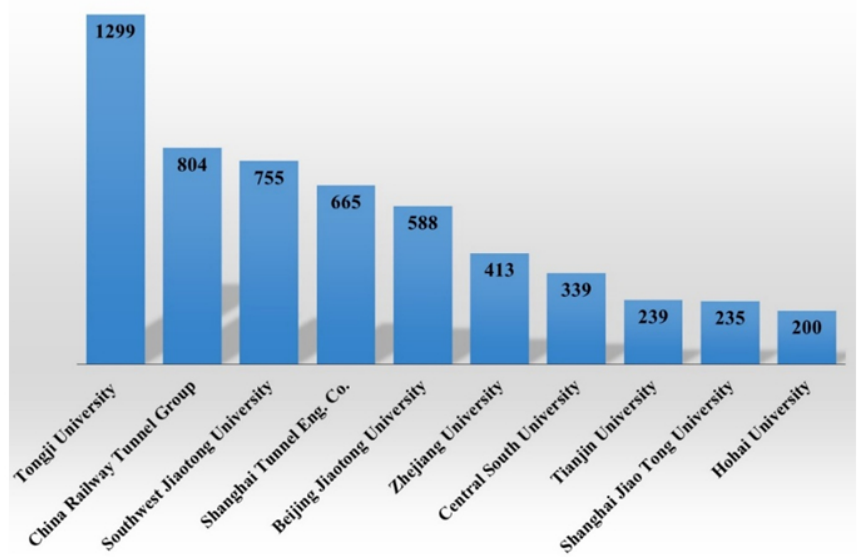

(b) Number of publications by top 10 Chinese research institutes

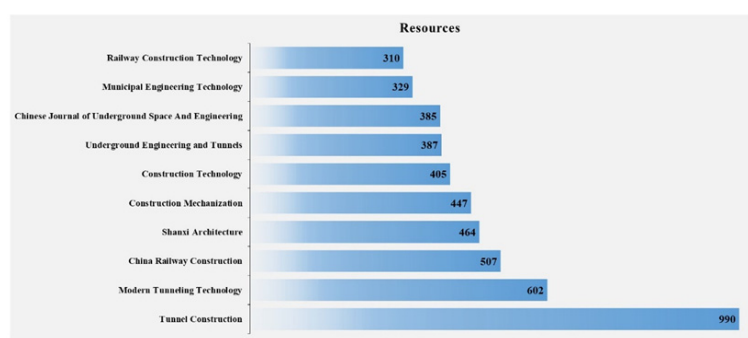

(c) Top 10 Chinese journals with the marked number of publications

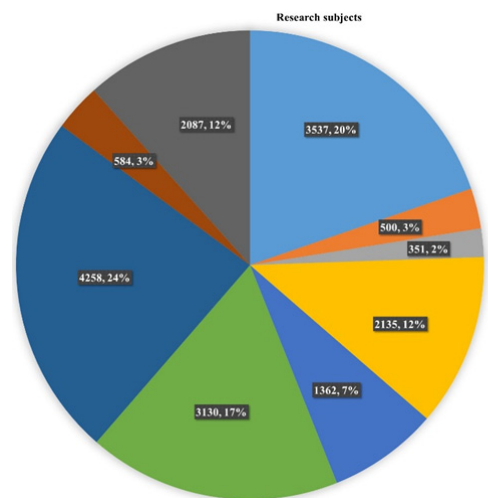

(d) Nine major research subjects related to TBM technology

Fig. 4. Research trend of TBM technology in China for the past two decades. 
published in Chinese which are difficult to access for Korean academics and industries, they are still worth referring to for our future research in TBM tunneling field.

With the increasing and wide application of TBMs, the TBM tunneling techniques have greatly evolved in China (Wang, 2014). The relevant content of TBM tunneling techniques will not be covered in this paper. However, some typical cases where key techniques of TBM tunneling in difficult (or complex) ground conditions can be found such as for mixed ground (Liao, 2012; Wang, et al., 2016), cobbly-bouldery ground (Yang et al., 2011; Le et al., 2012; Sun et al., 2017), super long tunnel with large diameter TBM (Deng, 2016; Wang, 2017), high geo-stress region (Fang et al., 2013; Song and Zhao, 2017), and underwater tunnel with high water pressure (Xiao, 2018; Zhu et al., 2018).

\section{State Key Laboratories (SKLs) in China}

To solve the technical challenges and ensure efficient TBM tunneling in complex geological conditions, China has increased the investment for TBM manufacturing and tunneling technology. Some specialized and professional research institutes have been established to carry out relevant research projects of TBM technology funded by the government.

Two state key laboratories have been established for the development of TBM technologies. The 'State Key Laboratory (SKL) of Full-Face Rock TBM' which belongs to NHI was founded in 2004. This laboratory has a series of advanced test facilities including a multifunction test system of TBM (Fig. 5).

The 'SKL of Shield TBM and Boring Technology' operated by CREG was set up in 2010. Since then, the laboratory has won a total of 35 scientific and technological achievements, including the first prize of State Science and Technology Progress Award in 2012. Some experimental facilities of the laboratory are shown in Fig. 6. Currently, three main research topics have been set:

(1) Cutterhead and cutting tool technologies: to make the design of cutterhead and cutting tools to accommodate different geological conditions; to study the key technologies of cutter geological adaptation; to establish the theory of high-efficient rock breaking for cutterhead and cutters; and to develop industry standard for cutting tool design and manufacturing.

(2) Control technology of shield TBM tunneling: to establish the information management system of shield TBM tunneling which can provide technical advice and technical service for tunneling projects.

(3) System integration technology: to develop the machine integration and control technology; and to develop remote automatic diagnosis system and intelligent decision system.

\section{Unique achievements and future plans of Chinese TBM technology}

Through the consistent effort from the Chinese TBM industry and academia, many unique advanced technologies have been developed including (1) New driving technology (such as permanent magnet synchronized driving technology and electro-hydraulic driving technology), (2) cutterhead and cutter repair technology (such as replacement of cutter tools under atmospheric pressure and robot-assisted detection and repair technology), (3) rapid muck removal technology (such as high-efficiency crushing technology of large boulders), and (4) adaptive technology for non-circular sections (Zhao and Chen, 2013; Chen et al., 2016; Wu et al., 2016; Chen and Zhou, 2017; Li, 2017).

The main development trends in the future are as follows:

1. Chinese TBM manufacturers are developing miniature TBMs for a build-up type shield TBM (several miniature TBMs to be assembled together). CREG has already applied a prototype machine to the construction of an underground parking lot.

2. TBMs for great depth with high geo-stress, high water pressure, and for large-diameter tunnels are under development to accommodate diverse demand for efficient tunnelling.

The adaptability of TBMs in the complex and difficult geological conditions, robustness of TBMs, and reliable cutter life would be even more demanding in the future (Wang, 2014; Liu et al., 2015). The long-term vision of Chinese TBM technology is to realize more efficient and automatic design, modular manufacturing, remote and intelligent monitoring, controlling and maintenance of TBMs. 


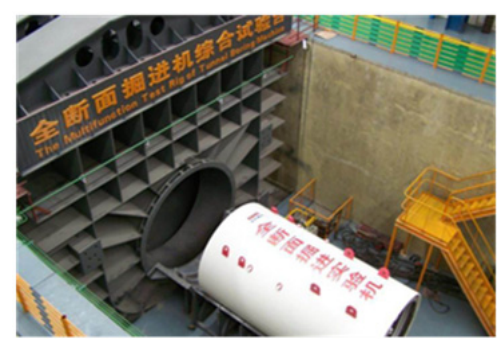

(a) Multifunction test rig

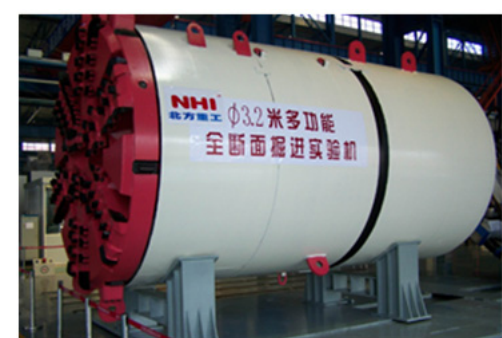

(b) Multifunction testing TBM $(\phi 3.2 \mathrm{~m})$

Fig. 5. Multifunction test system of TBM in the State Key Laboratory (SKL) of NHI.

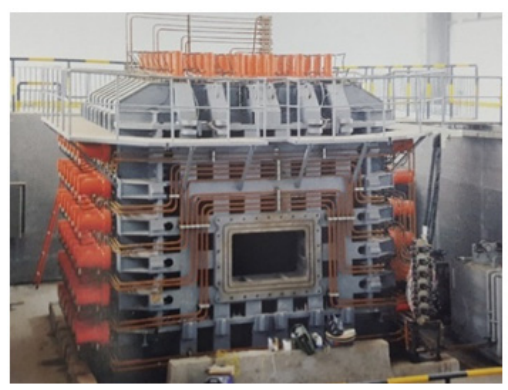

(a) Experimental platform of engineering structure

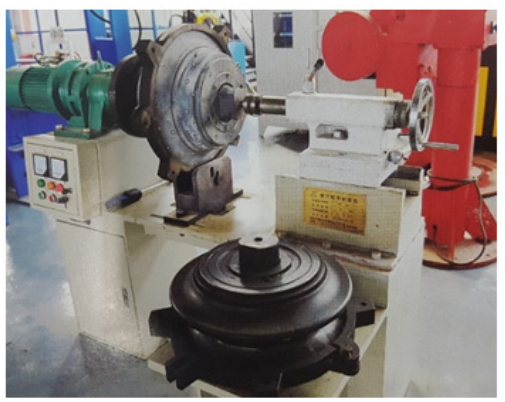

(c) Disc cutter testing platform

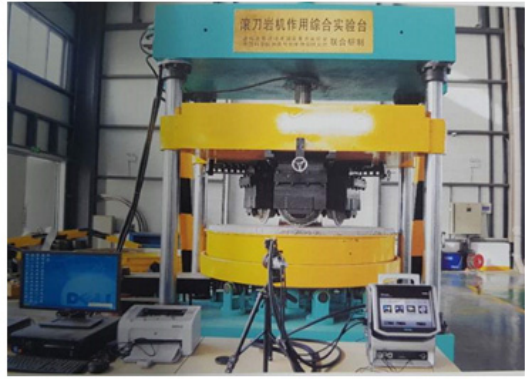

(b) Rotary cutting platform

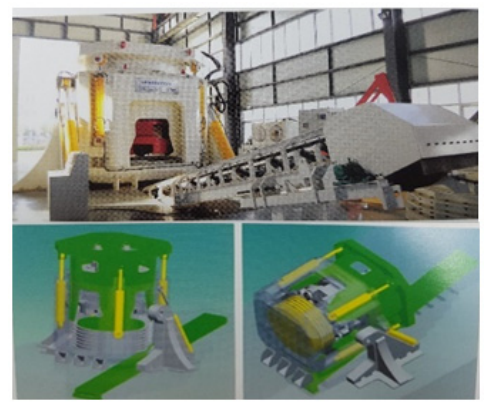

(d) Comprehensive experimental platform

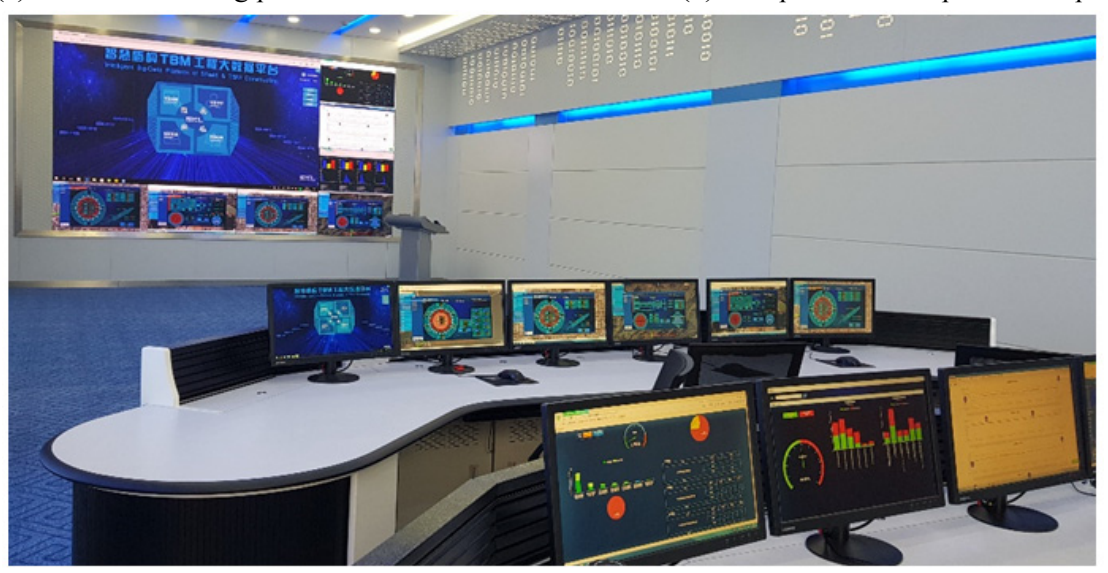

(e) Intelligent big data platform for TBM tunneling site

Fig. 6. Experimental platforms in the State Key Laboratory of CREG. 


\section{Conclusions}

China is the country that has the most tunneling projects in the world at present. Based on the diverse projects, the TBM manufacturing industry of China has rapidly grown in the past decades. Narrowing down the technological gap with advanced countries, the Chinese TBM industry still has tasks in enhancing the reliability of TBMs, independent technological innovation, and development of more intelligent design and manufacturing methodologies.

From the Chinese history of TBM technology development, some implications and beneficial enlightenment can be attained. TBM industry is technology- and capital-intensive. It requires huge initial capital investment and many engineering projects to apply its technologies. The Belt and Road Initiative (BRI) and strong governmental support made the Chinese TBM industry viable. Manufacturers have been working together with research institutes and universities in many projects. It is worth noting that the technical development could not be made without diverse tunneling projects, feedbacks from job sites, and modifications of the technologies.

TBM industry of Korea is small in size due to the limited number of national tunneling projects and the preference of cost-effective drill-and-blast tunneling over TBM tunneling in many cases. On the contrary, the Korean government has supported $\mathrm{R} \& \mathrm{D}$ projects for the development of core technologies in TBM design, subsea and utility tunnels by TBMs. In case that the government and the potential manufacturers are interested in TBMs, the Chinese history of TBM technology development will make an excellent case to refer to.

\section{Acknowledgement}

This study was funded by the Korea Agency for Infrastructure Technology Advancement under the Ministry of Land, Infrastructure and Transport in Korea (Project No. : 18SCIP-B105148-04).

\section{References}

Chen, K., Hong, K.R. and Jiao, S.J., 2016. Shield Construction Technique (2nd Ed.), China Communications Press, Beijing, China, 548p.
Chen, K. and Zhou, P., 2017. China Shield, Yilin Press, Beijing, China, 320p.

China Construction Machinery Association, 2018.04.20, http://info.cncma.org

Deng, M.J., 2016. Key techniques for group construction of deep-buried and super-long water transfer tunnel by TBM. Chinese J. of Geotechnical Engineering, 38(4), 577-587.

Fang, Y.M., Liu, N., Zhang, C.Q., Chu, W.J. and Chen, X.H., 2013. Rockburst risk control for large diameter TBM boring in high geostress region. Chinese J. of Rock Mechanics and Engineering, 32(10), 2100-2107.

Hong, K.R., Chen, K. and Feng, H.H., 2013. The innovation and breakthrough of shield technology in China. Tunnel Construction, 33(10), 801-808.

Hong, K.R., 2015. State-of-art and prospect of tunnels and underground works in China. Tunnel Construction, 35(2), 95-107.

Hong, K.R., 2017. Development and prospects of tunnels and underground works in China in recent two years. Tunnel Construction, 37(2), 123-134.

Le, G.P., He, S.H. and Luo, F.R., 2012. Beijing Subway Shield Tunneling Technology, China Communications Press, Beijing, China, 761p.

Li, J.B., 2017. Key Technologies and Applications of the Design and Manufacturing of Non-Circular TBMs. Engineering, 3(6), 905-914.

Liao, H.Y., 2012. Technology for Shield Tunnel in Mixed face ground conditions - Study \& Practice in Shield Tunneling projects of Guangzhou Metro, China Architecture \& Building Press, Beijing, China, 195p.

Liu, Q.S., Huang, X., Liu, J.P. and Pan, Y.C., 2015. A prospect of researches on interaction and safety control between TBM and deep mixed ground. J. of China Coal Society, 40(6), 1213-1224.

Ministry of Science and Technology of China, 2018.04.20, http://www.most.gov.cn

Song, F.L. and Zhao, H.L., 2017. Study of key construction technologies of open TBM in complex geological conditions: case study of gaoligongshan tunnel. Tunnel Construction, 37(S1), 128-133.

Sun, L.C., Zhang, Z., Wang, Z.H. and Wang, G.S., 2017. Construction Technology of EPB Shield in Waterless Sandy Cobble Stratum, China Communications Press, Beijing, China, 277p.

Wang, M.S., 2014. Tunnelling by TBM/shield in China: State of art, problems and proposals. Tunnel Construction. 34(3), 179-187.

Wang, H.D., Wei, K.L. and Zhu, W.B., 2016. Research on Shield Tunneling in Guangzhou line 6, China Communications 
Press, Beijing, China, 332p.

Wang, J.Y., 2017. Super large diameter shield tunneling technologies in China in recent decade. Tunnel Construction, 37(3), 330-335.

Wu, X.P., Liu, J., Zhu, H.J. and Fang, J.H., 2016. A Review of TBM Engineering in China, China Communications Press, Beijing, China, 703p.

Xiao, M.Q., 2018. Representative projects and development trend of underwater shield tunnels in China. Tunnel Construction, 38(3), 360-371.

Yang, S.J., Sun, M. and Hong, K.R., 2011. Shield Construction
Technology in Water-rich Sand and Cobble Stratum, China Communications Press, Beijing, China, 283p.

Yang, C. and Peng, F.L., 2016. Discussion on the development of underground utility tunnels in China. Procedia Engineering, $165,540-548$.

Zhao, H. and Chen, K., 2013. Discussion on the development direction of shield electro-hydraulic control technology. Design \& Research, 5, 54-86.

Zhu, Y.F., Li, L. and Wu, H.M., 2018. Extra-large undersea shield tunnel in composite ground: maliuzhou traffic tunnel in Zhuhai. Tunnel Construction, 38(3), 494-500.

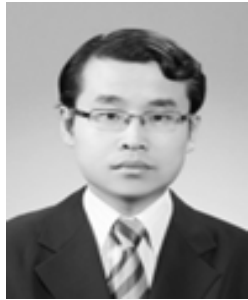

\section{장 난}

2004년 동북대학교 공과대학 토목공학 과 공학사

2008년 동북대학교 공과대학 지반공학 과 공학석사

2017년 서울대학교 대학원 에너지자원 공학과 공학박사

현재 서울대학교 에너지자원신기술연구소 박사후연구원 (E-mail; parisnan@snu.ac.kr)

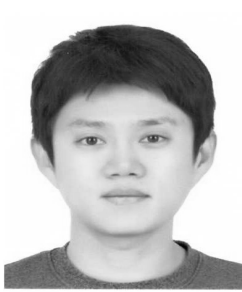

\section{정 호 영}

2008년 서울대학교 공과대학 지구환경 시스템공학부 공학사

2010년 서울대학교 대학원 에너지자원 공학과 공학석사

2017년 서울대학교 대학원 에너지자원 공학과 공학박사

현재 서울대학교 에너지자원신기술연구소 박사후연구원

(E-mail; hyjung04@snu.ac.kr)

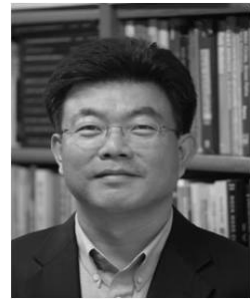

\section{전 석 원}

1987년 서울대학교 공과대학 자원공학 과 공학사

1989년 서울대학교 대학원 자원공학과 공학석사

1991년 (미)캘리포니아 주립대학 대학원 공학석사

1996년 (미)아리조나 주립대학 대학원 공학박사

현재 서울대학교 에너지시스템공학부 교수

(E-mail; sjeon@snu.ac.kr) 